\title{
PARTISIPASI PRIA DALAM PROGRAM KELUARGA BERENCANA (KB)
}

\author{
Reno Muhatiah \\ Dinas Kesehatan Kabupaten Kampar \\ E-mail: pangadilan@yahoo.co.id
}

\begin{abstract}
This article discusses the factors influence man participation in family planning program by using Preced of Green Behavioral Approach. The limited man participation in family planning because of the factor of predisposing actors which consist of knowledge, attitude, confidence, value, curltural, and perception, with reference to someone motivation or group to act. Enabling factors like personal or community resource and skill. The reinforcing factors is the determining factor whether the health action obtained support or not. This factor is a represent factor (incoming after) like attitude and behavior of elite community, religion figure, behavior and attitude all the officer including officer of health.
\end{abstract}

Kata Kunci: keluarga berencana, partisipasi wanita, partisipasi pria, kontrasepsi 


\section{PENDAHULUAN}

Indonesia dengan jumlah penduduk saat ini sekitar 215 juta jiwa merupakan negara keempat terbesar di dunia setelah Cina, India dan Amerika. Besarnya jumlah penduduk ini terkait dengan tingginya angka pertumbuhan penduduk Indonesia di masa lalu yang utamanya dipengaruhi oleh tingkat kelahiran. Meskipun tingkat kelahiran sudah dapat diturunkan namun secara absolut jumlah penduduk Indonesia masih terus bertambah. ${ }^{1}$

Berdasarkan proyeksi penduduk yang dirumuskan oleh Badan Pusat Statistik (BPS), perkiraan penduduk Indonesia pada tahun 2025 sekitar 273,65 juta jiwa. Laju pertumbuhan penduduk Indonesia tahun 1971-1980 adalah 2,10\%, tahun 1980-1990 sebanyak 1,97\%, tahun 1990-2000 adalah 1,49\% dan tahun 2000-2005 adalah 1,3\%. Sedangkan laju pertumbuhan penduduk di Propinsi Riau secara berturut-turut untuk tahun yang sama adalah 4,25\%, 4,22\%, 4,35\% dan 4,05\%. Angka ini menunjukkan laju pertumbuhan penduduk di Propinsi Riau masih lebih tinggi dari laju pertumbuhan penduduk Indonesia. ${ }^{2}$ Jumlah penduduk yang tinggi bila tidak didukung dengan kualitas yang memadai justru akan menjadi beban bagi pembangunan ekonomi. Kualitas sumber daya manusia kita masih tergolong rendah. Indeks pembangunan sumber daya manusia kita, menurut UNDP, berada pada peringkat ke-111 dari 177 negara. ${ }^{3}$

Semenjak tahun 1969, pemerintah sudah melakukan penekanan terhadap laju pertambahan penduduk dengan cara mengatur kelahiran, pendewasaan usia kawin, meningkatan ketahanan keluarga dan kesejahteraan keluarga yang disebut dengan program keluarga berencana (KB). Sayanganya, semenjak dicanangkannya program KB, hampir sebagian besar peserta KB adalah perempuan.

Terbatasnya jumlah peserta KB pria hampir merata di seluruh wilayah Indonesia. Data SDKI 2007 menunjukkan bahwa peserta KB Pria khususnya Vasektomi belum melebihi 1\%, sedangkan peserta KB Kondom baru mencapai sekitar 1,3\%. Sebagaimana halnya data tahun 2007, tahuntahun sebelumnya pencapaian peserta KB Pria belum mencapai 1\%. Pada tahun 1971 tercatat 0,6\% vasektomi dan 0,8\% kondom. Tahun 1994, Vasektomi $0,7 \%$ dan kondom 0,9\%. Tahun 1997, vasektomi 0,4\% dan kondom 0,7\%. Tahun 2002-2003, Vasektomi 0,4\% dan Kondom 0,9\%. tahun 2003 menunjukkan bahwa kesertaan pria dalam ber-KB baru mencapai 1,3\%, yaitu kondom 0,9\% dan vasektomi 0,4\% (SDKI 20022003). Ketidaksetaraan gender dalam bidang KB sangat berpengaruh pada keberhasilan program, sehingga pemerintah dalam RPJM (rencana 
pembangunan jangka menengah) menetapkan partisipasi pria dalam KB sebesar 4,5\% di tahun 2010 dan 6,5\% pada tahun 2015.4 Dengan menggunakan pendekatan faktor perilaku pada kerangka kerja PRECEDE dari Green, tulisan ini membahas faktor-faktor penyebab rendahnya partisipasi pria dalam mengikuti program keluarga berencana.

\section{PEMBAHASAN}

\section{Keluarga Berencana (KB)}

Keluarga Berencana (KB) adalah upaya peningkatan kepedulian dan peran serta masyarakat melalui pendewasaan usia perkawinan, pengaturan kelahiran, pembinaan ketahanan keluarga, peningkatan kesejahteraan keluarga untuk mewujudkan keluarga kecil, bahagian dan sejahtera. ${ }^{5}$ Program Keluarga Berencana merupakan bagian integral dari pembangunan sangat penting dalam mengendalikan pertumbuhan penduduk. Pelaksanaan Keluarga Berencana didasarkan atas adanya jumlah penduduk yang besar dengan kualitas rendah, laju pertumbuhan penduduk yang tinggi (2,1\%) untuk tahun 1961-1971, struktur umur yang kurang menguntungkan yaitu kelompok umur usia muda (0-14 th) relatif besar $(42,1 \%)$. Disamping itu persebaran dan kepadatan penduduk yang tidak seimbang sekitar $60 \%$ penduduk berdiam di pulau Jawa dan Bali serta angka kelahiran total (FTR) pada tahun 1971 sebesar 4,3 \%. ${ }^{6}$

Dengan kondisi tersebut maka langkah konkrit yang dilaksanakan oleh pemerintah yaitu dengan dibentuknya Lembaga Keluarga Berencana Nasional (LKBN) pada tahun 1968 yang berstatus sebagai lembaga semi pemerintah dan berfungsi mengembangkan keluarga berencana dan mengelola segala jenis bantuan untuk keluarga berencana di Indonesia. Pada tahun 1970 dengan SK Presiden No.8 tahun 1970, LKBN ditingkatkan statusnya menjadi Badan Koordinasi Keluarga Berencana Nasional (BKKBN) yang berstatus sebagai lembaga pemerintah Non Departemen. Maka sejak saat itu telah dimantapkan adanya pelaksanaan Program KB Nasional yang menjadi tanggung jawab pemerintah.

Sebagai tindak lanjut pelaksanaan program KB, maka perkembangan kebijaksanaan dituangkan didalam GBHN seperti halnya didalam tahun 1973 disebutkan bahwa agar pembangunan ekonomi dan peningkatan kesejahteraan rakyat dapat terlaksana dengan cepat, harus dibarengi dengan peraturan pertumbuhan jumlah penduduk melalui Program Keluarga Berencana, yang mutlak harus dilaksanakan dengan berhasil, karena kegagalan pelaksanaan keluarga berencana akan mengakibatkan hasil usaha pembangunan menjadi tidak berarti dan dapat membahayakan generasi yang akan datang. Pelaksanaan keluarga 
berencana ditempuh dengan cara-cara sukarela, dengan pertimbangan nilai agama dan Kepercayaan terhadap Tuhan Yang Maha Esa.

Usaha Pengendalian pertumbuhan penduduk diperluas dan diintensifkan melalu Gerakan Keluarga Berencana Nasional yang menjangkau seluruh lapisan masyarakat, sehingga dapat mempercepat perwujudan keluarga kecil, bahagia dan sejahtera. ${ }^{7}$ Dengan makin berkembangnya pelaksanaan Gerakan KB dalam mewujudkan keluarga kecil bahagia dan sejahtera, maka secara nasional komitmen politis telah mensahkan Undang-Undang No.10 tahun 1992 tentang perkembangan Kependudukan dan Pembangunan Keluarga Berencana Sejahtera.

Komitmen politis telah diperjelas dalam GBHN tahun 1993 yang menyebutkan bahwa Pembangunan Keluarga Sejahtera diarahkan kepada terwujudnya kehidupan keluarga sebagai wahana persemaian nilai-nilai agama dan nilai-nilai luhur budaya bangsa guna meningkatkan kesejahteraan keluarga dan membina ketahanan keluarga agar mampu mendukung kegiatan pembangunan. Gerakan Keluarga Berencana Nasional sebagai salah satu kegiatan pokok dalam upaya mencapai keluarga sejahtera diarahkan untuk mengendalikan laju pertumbuhan penduduk dengan cara menurunkan angka kelahiran untuk mencapai keseimbangan antara pertumbuhan penduduk dan pertumbuhan ekonomi sehingga terwujud peningkatan kesejahteraan keluarga. Gerakan Keluarga Berencana diupayakan agar makin membudaya dan makin mandiri melalui penyelenggaraan penyuluhan keluarga berencana, peningkatan kualitas dan kemudahan pelayanan.

Pada awalnya pendekatan keluarga berencana lebih diarahkan pada aspek demografi dengan upaya pokok pengendalian jumlah penduduk dan penurunan fertilitas (TFR). ${ }^{8}$ Dimana Program KB nasional merupakan salah satu program untuk meningkatkan kualitas penduduk, mutu sumberdaya manusia, kesehatan dan kesejahteraan sosial, yang selama ini dilaksanakan melalui pengaturan kelahiran, pendewasaan usia kawin, peningkatan ketahanan keluarga dan kesejahteraan keluarga. Meski demikian, konferensi Internasional tentang Kependudukandan Pembangunan (ICPD 1994) menyepakati perubahan paradigma, dari pendekatan pengendalian populasi dan penurunan fertilitas, menjadi lebih kearah pendekatan kesehatan reproduksi dengan memperhatikan hak-hak reproduksi dan kesetaraan gender. ${ }^{9}$

Sejalan dengan perubahan paradigma kependudukan dan pembangunan di atas, program KB di Indonesia juga mengalami perubahan orientasi dari nuansa demografis ke nuansa kesehatan reproduksi yang di dalamnya terkandung pengertian bahwa KB adalah 
suatu program yang dimaksudkan untuk membantu pasangan atau perorangan dalam mencapai tujuan reproduksinya. Hal ini mewarnai program KB era baru di Indonesia. ${ }^{10}$ Memasuki era baru program KB di Indonesia diperlukan adanya reorientasi dan reposisi program secara menyeluruh dan terpadu. Reorientasi dimaksud terutama ditempuh dengan jalan menjamin kualitas pelayanan keluarga berencana dan kesehatan reproduksi yang lebih baik serta menghargai dan melindungi hak-hak reproduksi yang menjadi bagian integral dari hak-hak azasi manusia yang bersifat universal.

Prinsip pokok dalam mewujudkan keberhasilan program KB dimaksudkan adalah peningkatan kualitas di segala bentuk serta kesetaraan dan keadilan gender melalui pemberdayaan perempuan serta peningkatan partisipasi pria.Disisi lain dengan berubahnya paradigma tersebut pelayanan $\mathrm{KB}$ dalam pengelolaan masalah kependudukan dan pembanguna $\mathrm{n}$ dipandang dari pendekatan pengendalian populasi dan penurunan fertilitas menjadi pendekatan yang berfokus pada kesehatan reproduksi serta hak-hak reproduksi harus lebih berkualitas dan memperhatikan hak-hak dari klien atau masyarakat dalam memilih metode kontrasepsi yang diinginkan. Paling tidak, pelayanan Keluarga Berencana $(\mathrm{KB})$ dapat memberikan metode-metode kontrasepsi yang seimbang, beragam dan aman terpercaya yang dapat digunakan oleh masing-masing Pasangan Usia Subur (PUS). ${ }^{11}$

\section{Partisipasi pria dalam program Keluarga Berencana (KB)}

Di dalam Sasaran Rencana Pembangunan Jangka Menengah (RPJM) tahun 2004-2009 dijelaskan bahwa partisipasi pria menjadi salah satu indikator keberhasilan program KB dalam memberikan kontribusi yang nyata untuk mewujudkan keluarga kecil berkualitas.Partisipasi pria/suami dalam KB adalah tanggung jawab pria/suami dalam kesertaan ber-KB, serta berperilaku seksual yang sehat dan aman bagi dirinya, pasangan dan keluarganya.

Bentuk partisipasi pria/suami dalam KB dapat dilakukan secara langsung dan tidak langsung. Partisipasi pria/suami secara langsung (sebagai peserta $\mathrm{KB}$ ) adalah pria/suami menggunakan salah satu cara atau metode pencegahan kehamilan, seperti kondom, vasektomi (kontap pria), serta KB alamiah yang melibatkan pria/suami (metode sanggama terputus dan metode pantang berkala).Sedangkan keterlibatan pria secara tidak langsung misalnya pria memiliki sikap yang lebih positif dan membuat keputusan yag lebih baik berdasarkan sikap dan persepsi, serta pengetahuan yang dimilikinya. ${ }^{12}$ 
Menurut BKKBN (2005), bentuk partisipasi pria dalam Keluarga Berencana dapat dilakukan secara langsung maupun tidak langsung, antara lain: partisipasi secara langsung adalah sebagai peserta KB dengan menggunakan salah satu cara atau metode pencegahan kehamilan, seperti: kondom, vasektomi (kontap pria), metode sanggama terputus dan metode pantang berkala/sistem kalender. Partisipasi pria secara tidak langsung adalah mendukung dalam ber-KB. Dengan cara (1) memilih kontrasepsi yang cocok yaitu kontrasepsi yang sesuai dengan keinginan dan kondisi istrinya, (2) membantu istrinya dalam menggunakan kontrasepsi secara benar, seperti mengingatkan saat minum pil KB, dan mengingatkan istri untuk kontrol, (3) membantu mencari pertolongan bila terjadi efek samping maupun komplikasi dari pemakaian alat kontrasepsi, (4) mengantarkan istri ke fasilitas pelayanan kesehatan untuk kontrol atau rujukan, (5) mencari alternatif lain bila kontrasepsi yang digunakan saat ini terbukti tidak memuaskan, (6) membantu menghitung waktu subur, apabila menggunakan metode pantang berkala, dan (7) menggantikan pemakaian kontrasepsi bila keadaan kesehatan istri tidak memungkinkan.

Selain sebagai peserta KB, suami juga dapat berperan sebagai motivator, yang dapat berperan aktif memberikan motivasi kepada anggota keluarga atau saudaranya yang sudah berkeluarga dan masyarakat disekitarnya untuk menjadi peserta $K B$, dengan menggunakan salah satu kontrasepsi.

\section{Faktor-Faktor yang mempengaruhi partisipasi pria dalam program KB}

Partisipasi pria baik dalam praktek KB maupun dalam pemeliharaan Kesehatan Ibu dan Anak termasuk pencegahan kematian maternal hingga saat ini masih rendah.Untuk menurunkan Angka Kematian Ibu, diperlukan gerakan nasional yang juga melibatkan semua pihak dengan program dan kegiatan yang komprehensif, terkait terukur dan seimbang yang pada akhirnya peran pria/suami dalam program KB akan mampu mendorong peningkatan kualitas pelayanan $\mathrm{KB}$, peningkatan kesetaraan dan keadilan gender, peningkatan penghargaan terhadap hak asasi manusia, dan berpengaruh positif dalam mempercepat penurunan angka kelahiran total (TFR), penurunan Angka Kematian Ibu (AKI), dan penurunan Angka Kematian Bayi (AKB).13

Faktor yang mempengaruhi partisipasi pria dalam Keluarga Berencana juga dapat lihat dengan menggunakan pendekatan faktor perilaku pada kerangka kerja PRECEDE dari Green (1991). Adapun faktor-faktor yang mempengaruhi perilaku ada 3 faktor utama, yaitu : 
faktor predisposisi (predisposingf actors), faktor pemungkin (enabling factors), dan faktor penguat (reinforcing factors). ${ }^{14}$

Faktor predisposisi merupakan faktor anteseden terhadap perilaku yang menjadi dasar atau motivasi bagi perilaku. Termasuk kedalam factor ini adalah pengetahuan, sikap, keyakinan, nilai, adat istiadat (budaya), dan persepsi, berkenaan dengan motivasi seseorang atau kelompok untuk bertindak. Faktor predisposisi sebagai preferensi pribadi yang dibawa seseorang atau kelompok ke dalam suatu pengalaman belajar. Preferensi ini mungkin mendukung atau menghambat perilaku sehat, dalam setiap kasus, faktor ini mempunyai pengaruh. Berbagai faktor demografis seperti status sosial ekonomi, umur, jenis kelamin, dan ukuran keluarga penting sebagai faktor demografis. Faktor pemungkin adalah faktor antesenden terhadap perilaku yang memungkinkan suatu motivasi atau aspirasi terlaksana. Termasuk didalam faktor pemungkin adalah keterampilan dan sumber daya pribadi atau komuniti. Seperti tersedianya pelayanan kesehatan, keterjangkauan, kebijakan, peraturan perundangan.Faktor penguat merupakan faktor penyerta (yang datang sesudah) perilaku yang memberikan ganjaran, insentif, atau hukuman atas perilaku dan berperan bagi menetap atau lenyapnya perilaku itu, yang termasuk kedalam faktor ini adalah faktor sikap dan perilaku tokoh masyarakat, tokoh agama, sikap dan perilaku para petugas termasuk petugas kesehatan.Faktor penguat adalah faktor yang menentukan apakah tindakan kesehatan memperoleh dukungan atau tidak. Sumber penguat tentu saja tergantung pada tujuan dan jenis program. Di dalam pendidikan pasien, penguat mungkin berasal dari perawat, dokter, pasien lain, dan keluarga. Apakah penguat ini positif ataukah negatif bergantung pada sikap dan perilaku orang lain yang berkaitan, yang sebagian diantaranya lebih kuat daripada yang lain dalam mempengaruhi perilaku.

Berdasarkan pendekatan di atas, temuan peneitian menunjukkan bahwa rendahnya partisipasi pria dalam keluarga berencana dan kesehatan reproduksi pada dasarnya tidak terlepas dari operasional program KB yang selama ini dilaksanakan mengarah kepada wanita sebagai sasaran. Demikian juga masalah penyediaan alat kontrasepsi yang hampir semuanya untuk wanita, sehingga terbentuk pola pikir bahwa para pengelola dan pelaksana program mempunyai persepsi yang dominan yakni yang hamil dan melahirkan adalah wanita, maka wanitalah yang harus menggunakan alat kontrasepsi. Oleh sebab itu, semenjak tahun 2000 pemerintah secara tegas telah melakukan berbagai upaya untuk meningkatkan partisipasi pria dalam keluarga berencana 
dan kesehatan reproduksi melalui kebijakan-kebijakan yang telah ditetapkan. ${ }^{15}$

Hal yang mendasar dalam pelaksanaan pengembangan program partisipasi pria untuk mewujudkan keadilan dan kesetaraan gender adalah dalam bentuk perubahan kesadaran, sikap, dan perilaku pria atau suami maupun isterinya tentang Keluarga Berencana dan Kesehatan Reproduksi. Untuk meningkatkan kesertaan KB pria, yang utama hendaklah diberi pengetahuan yang cukup tentang $\mathrm{KB}$ dan Kesehatan Reproduksi. Pengelola seyogyanya memahami, pengetahuan, sikap dan perilaku dalam berbagai isu serta memahami dalam hubungan pembagian kekuasaan antara pria dan wanita.

Kurang berperannya suami dalam program Keluarga Berencana dan Kesehatan Reproduksi disebabkan oleh pengetahuan suami mengenai KB secara umum relatif rendah, sebagaimana terungkap pada penelitian Suherni, dkk (1999) bahwa pria yang mengetahui secara lengkap tentang alat kontrasepsi wanita dan pria hanya 6.2\%. Itupun hanya diantara pria/suami yang menggunakan alat kontrasepsi. Hasil studi kualitatif BKKBN di DKI dan DIY tahun 1999, memperlihatkan bahwa sebagian besar pria mengetahui tujuan $\mathrm{KB}$ yaitu untuk mengatur kelahiran, membentuk keluarga yang bahagia serta menyadari bahwa KB itu penting. Hasil yang relatif sama juga dijumpai dari temuan studi di Jawa Tengah dan Jawa Timur (2001) yang dilakukan 393 pria kawin. Hasil studi ini memperlihatkan bahwa pengetahuan pria tentang pengertian dan tujuan KB pada umumnya cukup baik meskipun belum semua dapat menerangkan secara jelas. Lebih dari setengah responden (58\%)menyatakan bahwa KB bermaksud untuk mengatur jarak kelahiran, sebesar 43,5\% mengetahui bahwa KB bertujuan untuk mencegah kehamilan, dan yang mengetahui bahwa dengan menjadi peserta KB dapat membatasi kelahiran disampaikan oleh responden sebanyak $41.2 \% .26 .16$

Sumadi menambhkan bahwa rendahnya penggunaan kontrasepsi di kalan gan pria diperparah oleh kesan selama ini bahwa program KB hanya diperuntukan bagi wanita, sehingga pria lebih cenderung bersifat pasif. Hal ini juga nampak dari kecenderungan pengguna tenaga perempuan sebagai petugas dan promotor untuk kesuksesan program KB, padahal praktek KB merupakan permasalahan keluarga, dimana permasalahan keluarga adalah permasalahan sosial yang berarti juga merupakan permasalahan pria dan wanita. Disamping itu kurangnya partisipasi pria dalam penggunaan alat kontrasepsi adalah karena keterbatasan metode untuk pengaturan fertilitas yang dapat dipilih pria. 
Secara biologis pengendalian fertilitas pria lebih sulit dibanding wanita karena pria selalu dalam kondisi subur dengan jumlah sperma yang dihasilkan sangat banyak. Masalah lain untuk mengembangkan metode kontrasepsi baru bagi pria adalah kebutuhan dana yang sangat besar, sehingga menimbulkan hambatan dalampengembangannya. ${ }^{17}$

Pernyataan diatas sama dengan pendapat Dreman and Robey (1998), yang menyebutkan alasan rendahnya partisipasi pria dalam penggunaan alat kontrasepsi adalah adanya pandangan dalam program KB bahwa wanita merupakan klien utama karena wanita yang menjadi hamil, sehingga banyak metode kontrasepsi yang didesain untuk wanita, sedangkan metode kontrasepsi bagi pria sangat terbatas pengembangannya. Selanjutnya Rob, dkk (1999) mengatakan bahwa eksklusi pria dariprogram KB menjadi faktor penentu keterbatasan program KB yang dapat dicapai. Penggunaan metode kontrasepsi modern bagi pria di Indonesia kurang dapat berkembang sebagaimana yang diharapkan. Rendahnya keterlibatan pria dalam penggunaan metode kontrasepsi mantap (vasektomi) diakibatkan oleh adanya kekhawatiran para bapak setelah vasektomi mereka akan kehilangan kejantanannya. Hal ini sama dengan hasil penelitian yang dilakukan di Zambia oleh Chirambo (1992) bahwa pria takut terjadi impotensi karena vasektomi. Juga adanya salah persepsi dan pandangan yang negatif bahwa vasektomi itu sama dengan pengebirian, sehingga pria enggan untuk menjalani vasektomi. ${ }^{18}$ Di sisi lain, Endang menemukan bahwa hambatan budaya masih dominan terhadap kontrasepsi pria, khususnya kontrasepsi mantap.Hal tersebut didukung pendapat BKKBN (2007) bahwa kesertaan ber KB pria rendah terjadi karena faktor sosial budaya yangberanggapan bahwa KB adalah urusan perempuan sehingga pria tidak perlu berperan. ${ }^{19}$

Hasil penelitian Suprihastuti (2000) menyatakan bahwa adanya kemudahan dan ketersediaan sarana pelayanan ternyata berdampak positif terhadap penggunaan sesuatu alat kontrasepsi. Aksesibilitas pria terhadap informasi mengenai $\mathrm{KB}$ rendah karena masih terbatasnya informasi tentang peranan pria dalam KB dan KR; dan aksesibilitas pria terhadap sarana pelayanan kontrasepsi rendah. Dimana Puskesmas terdapat pelayanan KIA yang umumnya melayani Ibu dan Anak saja sehingga pria merasa enggan untuk konsultasi dan mendapat pelayanan, demikian pula terbatasnya jumlah sarana pelayanan yang dapat memenuhi kebutuhan pria serta waktu buka sarana pelayanan tersebut. ${ }^{20}$

Menurut BKKBN (2005) upaya peningkatan partisipasi pria terkendala oleh beberapa ketentuan peraturan daerah yang belum 
mengakomodir jenis kontrasepsi mantap pria, seperti halnya aspek biaya yang harus ditanggung peserta terlalu tinggi karena masuk rumpun tindakan operasi dirumah sakit umum daerah (RSUD). Dilain pihak biaya bantuan yang tersedia dari BKKBN jumlahnya terbatas dan tidak mampu menutupi biaya yang ditetapkan daerah. Penggunaan dana Asuransi keluarga miskin (ASKES GAKIN) belum lancar sebagaimana diharapkan. Kesepakatan antara pihak asuransi dengan pihak BKKBN sebagai penyedia data dandistribusi Kartu Askes masih mewarnai permasalahan di lapangan. Pelayanan Kontap juga terkendala oleh ketersediaan dan kesiapan tenaga pelayanan, dukungan sarana pelayanan juga menjadikendala di beberapadaerah, tenaga terlatih sudah banyak yang alih tugas, peralatan kurang lengkap. ${ }^{21}$

Bertrand (1994) menyebutkan bahwa faktor-faktor yang mempengaruhi pemakaian kontrasepsi, antara lain (1) faktor sosial dan individu, (2) nilai anak dan keinginan memilikinya, (3) permintaan KB, (4) faktor intermediate lain (Umur Menarchea, umur kawin, mati haid, postpartum infecundability, fecundabilitas, anak lahir mati, aborsi disengaja), (5) program pembangunan, (6) faktor persediaan KB, (7) output pelayanan (akses, kualitas pelayanan, image), pemanfaatan pelayanan. ${ }^{22}$

\section{Faktor sosial dan individu}

Pengaruh faktor individu dan sosial (karakteristik individu) terhadap pemakaian kontrasepsi meliputi : (a) hubungan antara umur dengan pemakaian kontrasepsi. Kesehatan pasangan usia subur sangat mempengaruhi kebahagiaan dan kesejahteraan keluarga waktu melahirkan, jumlah kelahiran atau banyaknya anak yang dimiliki dan jarak anak tiap kelahiran. Maka dari itu umur merupakan salah satu faktor seseorang untuk menjadi akseptor kontap, sebab umur berhubungan dengan potensi reproduksi dan juga untuk menentukan perlu tidaknya seseorang melakukan vasektomi dan tubektomi sebagai cara kontrasepsi. (b) Hubungan pendidikan dengan pemakaian kontrasepsi. Purwoko (2000), mengemukakan pendidikan merupakan salah satu faktor yang dapat mempengaruhi pengetahuan dan sikap tentang metode kontrasepsi. Orang yang berpendidikan tinggi akan memberikan respon yang lebih rasional daripada mereka yang berpendidikan rendah, lebih kreatif dan lebih terbuka terhadap usaha-usaha pembaharuan. Hubungan Jumlah anak dengan pemakaian kontrasepsi. Jumlah anak yang dimiliki, paritas 2-3 merupakan paritas paling aman ditinjau dari sudut kematian maternal. Paritas 1 dan paritas lebih dari 3 mempunyai angka kematian maternal. Resiko pada paritas 1 dapat ditangani dengan 
asuhan obstetri lebih baik, sedangkan resiko pada paritas tinggi dapat dikurangi atau dicegah dengan keluarga berencana yang salah satunya menggunakan kontrasepsi mantap yaitu vasektomi dan tubektomi. Jumlah anak hidup mempengaruhi pasangan usia subur dalam menentukan metode kontrasepsi yang akan digunakan. Pada pasangan dengan jumlah anak hidup masih sedikit terdapat kecenderungan untuk menggunakan metode kontrasepsi dengan efektivitas rendah, sedangkan pada pasangan dengan jumlah anak hidup banyak terdapat kecenderungan menggunakan metode kontrasepsi dengan efektivitas tinggi. (d) Hubungan pendapatan dengan pemakaian kontrasepsi.Tingkat pendapatan suatu keluarga sangat berpengaruh terhadap kesertaan suami dalam berKB. Nampaknya, bila PUS keduanya bekerja, berarti istri tidak bekerja atau memiliki pendapatan sendiri. Hasil penelitian Wijayanti (2004) akibat ketidak tahuan masyarakat di desa Timpik tentang metode MOP, mereka mengemukakan berbagai alasan, salah satunya biaya MOP atau vasektomi yang mahal. Alasan tersebut dikaitkan dengan penghasilan mereka sebagai petani kecil dan mereka menganggap tidak akan mampu menjangkau metode ini. Pernyataan responden bahwa biaya pelaksanaan MOP ini mahal, bila dibandingkan dengan metode kontrasepsi lainnya sebetulnya bisa dikatakan lebih murah, karena metode ini hanya dilakukan sekali selamanya. Sedangkan untuk metode lain, misalnya IUD yang sekali pasang hanya untuk jangka waktu tertentu, yang mana setelah itu harus dilepas dan tentunya dipasang lagi bila masih menginginkan metode kontrasepsi yang tentunya membutuhkan biaya lagi. Inilah yang membuktikan bahwa metode lain justru lebih mahal dari pada MOP. Salah satu keuntungan dari alat kontrasepsi vasektomi adalah biaya rendah. Sesungguhnya metode kontrasepsi pria relatif tidak mahal. Akan tetapi meskipun pria mampu untuk menggunakan metode kontrasepsi vasektomi, pria tetap memilih menggunakan metode kontrasepsi lain seperti kondom. Alasan ini diungkapkan oleh pria karena metode kontrasepsi kondom lebih sederhana dan tidak memerlukan tindakan dari tenaga medis. ${ }^{23}$

\section{Nilai anak dan keinginan memilikinya}

Pengaruh nilai anak dan keinginan memilikinya terhadap pemakaian kontrasepsi. Anak memiliki nilai universal namun nilai anak tersebut sangat dipengaruhi oleh faktor sosio kultural dan lain-lain. Pandangan orang tua mengenai nilai anak danjumlah anak dalam keluarga dapat merupakan hambatan bagi keberhasilan program KB. 


\section{Permintaan KB}

Permintaan $\mathrm{KB}$ terhadap pemakaian kontrasepsi keinginan atau kemauan (want) yang diterjemahkan ke dalam perilaku mencari pelayanan (pemeliharaan) kesehatan disebut permintaan atau tuntutan (demands). Permintaan adalah suatu fungsidari kebutuhan (needs) dan faktor-faktor lain termasuk kemampuan pelayanan dan keadaan sosioekonomi seperti income, kelas sosial, dan besar keluarga.

Intermediate lain (umur menarchea, umur kawin, mati haid, postpartum infecundability, fecundabilitas, anak lahir mati, aborsi disengaja)

Pengaruh output pelayanan terhadap pemakaian kontrasepsi yang terdiri dari: (1) keterjangkauan fisik agar tempat pelayanan lebih mudah menjangkau dan dijangkau oleh masyarakat sasaran, khususnya pria, (2) keterjangkauan ekonomi agar biaya pelayanan dapat dijangkau oleh klien. Biaya untuk memperoleh pelayanan menjadi bagian penting bagi klien. Biaya klien meliputi : uang, waktu, kegiatan kognitif dan upaya perilaku serta nilai yang akan diperoleh klien. Untuk itu dalam mengembangkan pelayanan gratis atau subsidi perlu pertimbangan biaya pelayanan dan biaya klien, (3) Keterjangkauan psikososial yaitu untuk meningkatkan penerimaan partisipasi pria dalam KB secara sosial dan budaya oleh masyarakat, provider, pengambil kebijakan, tokoh agama, tokoh masyarakat, (4) Keterjangkauan pengetahuan agar pria mengetahui tentang pelayanan KB serta dimana mereka dapat memperoleh pelayanan tersebut dan besarnya biaya untuk memperolehnya, (5) Keterjangkauan administrasi agar ketetapan administrasi medis dan peraturan yang berlaku pada semua aspek pelayanan berlaku untuk pria dan wanita. Selama ini dirasakan faktor aksesabilitas atau keterjangkauan pelayanan KB dan KR bagi pria masih sangat terbatas. Aksesabilitas informasi KB dan KR baik media KIE, konseling yang tersedia, informasi yang diberikan oleh petugas, tempat pelayanan yang ada masih bias gender.

\section{Kualitas pelayanan $\mathrm{KB}$.}

Bruce (1990) menjelaskan bahwa terdapat enam komponen dalam kualitas pelayanan, yaitu pilihan kontrasepsi, informasi yang diberikan, kemampuan tehnikal, hubungan interpersonal, tindak lanjut atau kesinambungan, kemudahan pelayanan. Dalam kerangka teorinya disebutkan pula bahwa dampak dari kualitas pelayanan adalah pengetahuan klien, kepuasan klien, kesehatan klien, penggunaan kontrasepsi penerimaan dan kelangsungannya. Enam elemen kualitas pelayanan di atas saling berkaitan antara yang satu dengan unsur yang 
lainnya. Keterkaitan ini dipengaruhi oleh faktor latar belakang yang sama, yaitu kebijaksanaan politis, sumber alokasi, managemen program. Dari ketiga unsur yaitu pengelola, pelaksana, dan klien dapat diidentifikasi untuk dapat memberikan penilaian pada setiap elemen tersebut dapat membahas untuk konsep dan indicator kualitas pelayanan KB. Kualitas yang diterima oleh klien menjadi fokus pokok untuk menilai kualitas pelayanan.

\section{Image atau penerimaan $\mathrm{KB}$}

Pengertian penerimaan menurut Kamus Besar Bahasa Indonesia adalah sikap terhadap. Lebih dapat dijelaskan lagi bahwa sikap merupakan reaksi terhadap objek di lingkungan tertentu sebagai suatu penghayatan terhadap objek.55 Menurut penjelasan yang disampaikan oleh Bidan di propinsi Sumatra Barat dan Sumatra Selatan menyatakan bahwa hampir semua Tokoh Masyarakat (TOMA) dan suami yang ada di wilayah penelitian ini belum bisa menerima KB Pria terutama Vasektomi. Alasannya, agama tidak memperbolehkan, kecuali bila cara KB lainnya bisa mengancam jiwa istri.

\section{Pemanfaatan pelayanan}

Pengaruh pemanfaatan pelayanan terhadap pemakaian kontrasepsi. Adanya kemudahan dan ketersediaan sarana pelayanan berdampak positif terhadap penggunaan suatu alat kontarsepsi. Studi dari Jawa Tengah dan Jawa Timur (2001) menemukan alasan inilah yang menjadi faktor utama di dalam memilih tempat pelayanan KB Pria yang paling disukai. Hal ini dinyatakan oleh sebagian besar responden terutama pria yang mengatakan bahwa pria perlu berpartisipasi dalam KB. Menurut mereka pelayanan KB pria yang dekat dengan rumah atau dekat dari tempat mereka bekerja merupakan tempat pelayanan yang paling disukai $(48.8 \%)$. Sebanyak $12.8 \%$ responden menginginkan tempat pelayanan dengan transportasi mudah (12.7\%), biaya terjangkau (9.9\%), fasilitas lengkap (9.3\%), dilayani dengan tenaga yang ahli dan ramah (9\%), dan dapat menjaga privacy $(2.2 \%) .{ }^{24}$

Menurut BKKBN (2007) faktor-faktor yang mempengaruhi rendahnya partisipasi pria dalam $\mathrm{KB}$ antara lain : terbatasnya sosialisasi dan promosi KB pria; adanya persepsi bahwa wanita yang menjadi target program $\mathrm{KB}$; terbatasnya akses pelayanan $\mathrm{KB}$ pria; tingginya harga yang harus dibayar untuk MOP; ketidaknyamanan dalam penggunaan KB pria (kondom); terbatasnya metode kontrasepsi pria; rendahnya pengetahuan pria terhadap $\mathrm{KB}$; kualitas pelayanan $\mathrm{KB}$ pria belum memadai; istri tidak 
mendukung suami ber-KB; adanya stigmatisasi tentang $\mathrm{KB}$ pria di masyarakat; kondisi politik, sosial, budaya masyarakat, agama, dan komitmen pemerintah masih belum optimal dalam mendukung KB pria; penerapan Program Kebijakan Partisipasi Pria di lapangan masih belum optimal. ${ }^{25}$

Di daerah pedesaan, anak mempunyai nilai yang tinggi bagi keluarga. Anak dapat memberikan kebahagiaan kepada orang tuanya. Selain itu akan merupakan jaminan di hari tua dan dapat membantu ekonomi keluarga. Banyak masyarakat desa di Indonesia yang berpandangan bahwa banyak anak banyak rejeki. Dari penelitian Mohamad Koesnoe di daerah Tengger, petani yang mempunyai tanah luas akan mencari anak angkat sebagai tambahan tenaga kerja. Studi lain yang dilakukan oleh proyek VOC (Value Of Children) menemukan bahwa keluarga-keluarga yang tinggal di pedesaan Taiwan, Philipina, Thailand mempunyai anak yang banyak dengan alasan bahwa anak memberikan keuntungan ekonomi dan rasa aman bagi keluarganya. ${ }^{26}$

Adat kebiasaan atau adat dari suatu masyarakat yang memberikan nilai anak laki-laki lebih dari anak perempuan atau sebaliknya. Hal ini akan memungkinkan satu keluarga mempunyai anak banyak. Bagaimana kalau keinginan untuk mendapatkan anak laki-laki atau perempuan tidak terpenuhi? Mungkin akan menceraikan istrinya dan kawin lagi agar terpenuhi keinginan memiliki anak laki-laki ataupun anak perempuan. Disinilah norma adat istiadat perlu diluruskan karena tidak banyak menguntungkan, bahkan banyak bertentangan dengan kemanusiaan. ${ }^{27}$

Bagi para pemeluk agama, merencanakan jumlah anak adalah menyalahi kehendak Tuhan. Kita boleh mendahului kehendak Tuhan, apalagi mencegah kelahiran anak dengan menggunakan alat kontrasepsi supaya tidak hamil. Langkah utama untuk mengatasi hal ini adalah menemui tokoh-tokoh atau ulama dari agama tersebut untuk menjelaskan bahwa merencanakan keluarga untuk membantu keluarga kecil adalah tidak bertentangan dengan agama. ${ }^{28}$

\section{SIMPULAN}

Keluarga Berencana (KB) merupakan upaya peningkatan kepedulian dan peran serta masyarakat melalui pendewasaan usia perkawinan, pengaturan kelahiran, pembinaan ketahanan keluarga, peningkatan kesejahteraan keluarga untuk mewujudkan keluarga kecil, bahagian dan sejahtera. Untuk mencapai tujun tersebut maka partisipasi pasangan suami istri sangat diharapkaan. Namun pada kenyataannya, partisipasi wanita jauh lebih besar jumlahnya dari pada pria. randahnya 
partisipasi pria dalam mengikuti program keluarga berencana hampir merata di sluruh wilayah di Indonesia.

Banyak faktor yang menyebabkan rendahnya partisipasi pria dalam megikuti program keluarga berencana (KB). Faktor tersebut antara lain faktor predisposisi (predisposingf actors), faktor pemungkin (enabling factors), dan faktor penguat (reinforcing factors). Faktor predisposisi merupakan faktor anteseden terhadap perilaku yang menjadi dasar atau motivasi bagi perilaku, seperti pengetahuan, sikap, keyakinan, nilai, adat istiadat (budaya), dan persepsi, berkenaan dengan motivasi seseorang atau kelompok untuk bertindak. Faktor predisposisi sebagai preferensi pribadi yang dibawa seseorang atau kelompok ke dalam suatu pengalaman belajar. Preferensi ini mungkin mendukung atau menghambat perilaku sehat, dalam setiap kasus, faktor ini mempunyai pengaruh. Berbagai faktor demografis seperti status sosial ekonomi, umur, jenis kelamin, dan ukuran keluarga penting sebagai faktor demografis.

Faktor pemungkin adalah faktor antesenden terhadap perilaku yang memungkinkan suatu motivasi atau aspirasi terlaksana. Termasuk didalam faktor pemungkin adalah keterampilan dan sumber daya pribadi atau komuniti, seperti tersedianya pelayanan kesehatan, keterjangkauan, kebijakan, peraturan perundangan. Faktor penguat merupakan faktor penyerta (yang datang sesudah) perilaku yang memberikan ganjaran, insentif, atau hukuman atas perilaku dan berperan bagi menetap atau lenyapnya perilaku itu. Yang termasuk kedalam faktor ini adalah faktor sikap dan perilaku tokoh masyarakat, tokoh agama, sikap dan perilaku para petugas, termasuk petugas kesehatan. Faktor penguat adalah faktor yang menentukan apakah tindakan kesehatan memperoleh dukungan atau tidak. Sumber penguat tentu saja tergantung pada tujuan dan jenis program.

\section{Endnotes:}

1 Badan Koordinasi keluarga Berencana Nasional. 2006. Keluarga Berencana, Kesehatan Reproduksi, Gender, dan Pembangunan Kependudukan. Hlm. 1

2 Badan Statistik Indonesia. Laju Pertumbuhan Penduduk Per Tahun menurut Provinsi. Disitasi dari : http://www.datastatistik-indonesia.com

3 Loc.Cit

$4 \quad$ Ibid. hlm.167

5 BKKBN. Gender dalam Program KB dan KR. http://gemapria.bkkbn.go.id/artikel022I.html. 2007.

6 BKKBN. Fakta, Data dan Informasi Kesenjangan Gender di Indonesia. BKKBN.Jakarta. 2001 
$7 \quad$ BKKBN. Pedoman Penggarapan Peningkatan Partisipasi Pria. BKKBN. Jakarta. 2000.

8 Satria, Yurni. Isu Gender dalam Kesehatan Reproduksi. Pusat Pelatihan Gender dan Peningkatan Kualitas Perempuan BKKBN. Jakarta. 2005.

$9 \quad$ Ibid

10 Samudro, Seno. Boyolali Raih Juara I KB Pria. http://www.bkkbn.go.id/jateng/ news_detail.php?nid $=19.2007$.

11 BKKBN. Pedoman Penggarapan Peningkatan Partisipasi Pria. BKKBN. Jakarta

12 Utarini. Men's Convolvement in Family Planning. Yogyakarta. 1998.karta. 2000

13 BKKBN. Peran Pria melalui Program KB dalam Kesehatan Maternal. Gema Partisipasi Pria. Jakarta.2000

14 Notoatmodjo, S. Promosi Kesehatan dan Ilmu Perilaku. Rineka Cipta. 2007.

15 Ibid, hal 56

16 Suprihastuti, dkk. Analisis Data Sekunder SDKI 97 Pengambilan Keputusan Peng gunaan Alkon Pria di Indonesia. D.I. Yogyakarta. 2000.

17 Sureni, dkk. Studi Gender Peranan Pria dalam Penggunaan Kontrasepsi di propinsi DIY. Kanwil BKKBN DIY \& PSW UMY. Yogyakarta. 1999.

18 Rahardjo, S. Panduan Pelayanan Vasektomi Tanpa Pisau. PKMI. Jakarta. 1995.

19 BKKBN. Gender dalam Program KB dan KR.

20 Asan, A. Hak Reproduksi sebagai Etika Global dan Implementasinya dalam Pelayanan KB/KR di NTT 2007. BKKBN. NTT. 2007

$21 \quad$ BKKBN. Peningkatan Partisipasi Pria dalam KB \& KR. BKKBN. Jakarta. 2005.

22 Bertrand. Kerangka Pikir Konseptual Permintaan KB serta Dampak Pada Fertilitas. Dalam: $B K K B N$. Peningkatan Akses dan Kualitas Pelayanan

23 Wetson. Para Wanita Mempercayai Pasangan Untuk Menggunakan Kontrasepsi Pria. http:// pikas.bkkbn.go.id. 2002.

$24 \quad$ Ibid

18 Endang. Buku Sumber Keluarga Berencana, Kesehatan Reproduksi, Gender, dan Pembangunan Kependudukan. BKKBN \& UNFPA. Jakarta

25 BKKBN. Faktor-Faktor yang mempengaruhi Rendahnya Partisipasi Pria dalam KB. http:// www.bkkbn.go.id/gemapria/info-detail.php?infid=79, 200

26 Siregar, F. Pengaruh nilai dan jumlah anak pada keluarga terhadap norma keluarga kecil bahagia dan sejahtera (NKKBS). http://library.usu.ac.id/modules.php?op $=$ modload $\&$ name $=$ Downloads $\&$ file=index\&req= getit\&lid=625. 2003.

$27 \quad$ Ibid

$28 \quad$ Ibid

\section{DAFTAR PUSTAKA}

Asan, A. 2007. Hak Reproduksi sebagai Etika Global dan Implementasinya dalam Pelayanan KB/KR di NTT 2007. BKKBN. NTT.

Badan Statistik Indonesia. Laju Pertumbuhan Penduduk Per Tahun menurut Provinsi. Disitasi dari: http:/ / www.datastatistik-indonesia.com

Bertrand. Kerangka Pikir Konseptual Permintaan KB serta Dampak Pada Fertilitas. Dalam: BKKBN. Peningkatan Akses dan Kualitas Pelayanan

BKKBN. 2000. Pedoman Penggarapan Peningkatan Partisipasi Pria. Jakarta: BKKBN. 
- 2000. Faktor-Faktor yang mempengaruhi Rendahnya Partisipasi Pria dalam KB. http://www.bkkbn.go.id/gemapria/info-detail.php? infid $=79$.

2000. Peran Pria melalui Program KB dalam Kesehatan Maternal. Jakarta: Gema Partisipasi Pria.

- 2001. Fakta, Data dan Informasi Kesenjangan Gender di Indonesia. Jakarta: BKKBN.

2005. Peningkatan Partisipasi Pria dalam KB $\mathcal{E}$ KR. Jakarta: BKKBN.

-------. 2006. Keluarga Berencana, Kesehatan Reproduksi, Gender, dan Pembangunan Kependudukan.

2007. Gender dalam Program KB dan KR. http://gemapria.bkkbn. go.id/ artikel02-2I.html.

Endang. Buku Sumber Keluarga Berencana, Kesehatan Reproduksi, Gender, dan Pembangunan Kependudukan. BKKBN \& UNFPA. Jakarta

Notoatmodjo, S. 2007. Promosi Kesehatan dan Ilmu Perilaku. Rineka Cipta.

Rahardjo, S. 1995. Panduan Pelayanan Vasektomi Tanpa Pisau. PKMI. Jakarta.

Samudro, Seno. 2007. Boyolali Raih Juara I KB Pria. http:/ / www.bkkbn.go.id/ jateng/news_detail.php?nid =19.

Satria, Yurni. 2005. Isu Gender dalam Kesehatan Reproduksi. Jakarta: Pusat Pelatihan Gender dan Peningkatan Kualitas Perempuan BKKBN.

Siregar, F. 2003. Pengaruh Nilai dan Jumlah Anak pada Keluarga terhadap Norma Keluarga Kecil Bahagia Dan Sejahtera (NKKBS). http:/ / library.usu.ac.id/modules. php?op=modload\&name=Downloads\&file $=$ index\&req=getit\&lid $=$ 625.

Suprihastuti, dkk. 2000. Analisis Data Sekunder SDKI 97 Pengambilan Keputusan Peng gunaan Alkon Pria di Indonesia. D.I. Yogyakarta.

Sureni, dkk. 1999. Studi Gender Peranan Pria dalam Penggunaan Kontrasepsi di propinsi DIY. Yogyakarta: Kanwil BKKBN DIY \& PSW UMY.

Utarini. 2000. Men's Convolvement in Family Planning. Yogyakarta.

Wetson. 2002. Para Wanita Mempercayai Pasangan untuk Menggunakan Kontrasepsi Pria. http://pikas.bkkbn.go.id. 


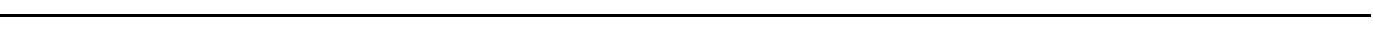

